\title{
Faktor-Faktor yang Mempengaruhi Perilaku Nelayan Artisanal dalam Pemanfaatan Sumberdaya Perikanan di Pantai Utara Provinsi Jawa Barat
}

\section{Factors Influencing Behavior of Artisanal Fishermen in Utilizing Fishery Resources in the North Coast of West Java Province}

\author{
Prihandoko ${ }^{1}$, Amri Jahi ${ }^{2}$, Darwis S Gani ${ }^{2}$, I Gusti Putu Purnaba ${ }^{3}$, \\ Luky Adrianto $^{4}$, dan Iwan Tjitradjaja ${ }^{5}$ \\ ${ }^{1}$ Universitas Indonesia, Jakarta \\ ${ }^{2}$ Departemen Sains Komunikasi dan Pengembangan Masyarakat \\ Fakultas Ekologi Manusia, Institut Pertanian Bogor, Bogor \\ ${ }^{3}$ Fakultas Ilmu Matematikan dan Pengetahuan Alam, Institut Pertanian Bogor, Bogor \\ ${ }^{4}$ Departemen Manajemen Sumberdaya Perairan, Fakultas Perikanan dan \\ Ilmu Kelautan, Institut Pertanian Bogor. Bogor \\ ${ }^{5}$ Departemen Antropologi, Fakultas Ilmu Sosial dan Ilmu Politik, Universitas Indonesia, Jakarta
}

\begin{abstract}
This study aims to estimate accurately the behavior using the Theory of Planned Behavior perspective of artisanal fishermen in Indonesi., The population of artisanal fishermen in the northern coast of West Java Province 10,404. Techniques for sampling by cluster random sampling clusters with the number of household sample of 400 artisanal fishermen. Data was collected using a questionnaire interview further processed using the program structural equation model (SEM) and LISREL 8:54. The conclusion of this study were (1) Theory of Planned Behavior perspective can be used to view the behavior intention of artisanal fishermen in the northern coast of West Java province; (2) the coefficient of determination between the attitude variables, subjective norm, perceived behavior control to variable behavior intention at 0,64. Meanwhile the influence of variables on behavior intention to behavior by 0,68 indicates that it is not fully manifested the behavior intention in accordance with the behavior of fishermen in their fishing activities, (3) that explains the study's findings about contribution of the Theory Planned Behavior perspective to the problem of coastal common resource and can contribute to the activities of co-management of fisheries in Indonesia, especially in communities in the study area on the northern coast of West Java Province.
\end{abstract}

Keywords: artisanal fishermen behavior, behavior intention, attitude, subjective norm, perceived behavior control

\section{Abstrak}

Penelitian ini bertujuan untuk memperkirakan perilaku secara akurat dengan menggunakan perspektif Theory Planned Behavior dari nelayan artisanal di Indonesia. Jumlah populasi nelayan artisanal di pantai Utara Provinsi Jawa Barat 10.404 rumah tangga. Teknik penarikan sampel dilakukan dengan cara acak kluster dengan jumlah sampel 400 rumah tangga. Data dikumpulkan dengan menggunakan wawancara kuesioner selanjutnya diproses dengan menggunakan program structural equation model (SEM) and LISREL 8:54. Kesimpulan dari penelitian ini adalah (1) perspektif Theory Planned Behavior dapat digunakan untuk melihat niat untuk berperilaku dan perilaku nelayan artisanal di pantai Utara Provinsi Jawa Barat; (2) koefisien determinasi antara peubah sikap (Atitude), norma subjektif (Subjective Norm), keyakinan kemampuan berperilaku (Perceived Behavior Control) terhadap peubah niat untuk berperilaku sebesar 0,64. Sementara itu pengaruh peubah niat untuk berperilaku terhadap perilaku sebesar 0,68 mengindikasikan bahwa tidak sepenuhnya niat untuk berperilaku nelayan terwujud sesuai dengan perilaku mereka dalam kegiatan perikanan tangkap; (3) temuan penelitian ini menjelaskan tentang kontribusi Theory Planned Behavior terhadap persoalan sifat kepemilikan ikan laut sebagai sumber milik bersama dan kontribusi terhadap kegiatan ko-manajemen perikanan di Indonesia khususnya pada komunitas di wilayah studi di pantai Utara Provinsi Jawa Barat.

Kata kunci: perilaku nelayan artisanal, niat untuk berperilaku, sikap, norma subjektif, keyakinan kemampuan berperilaku

\section{Pendahuluan}

Memperkirakan perilaku secara akurat dengan menggunakan perspektif Theory Planned Behavior (teori perilaku yang direncanakan) dari nelayan artisanal di Indonesia, khususnya di pantai Utara
Provinsi Jawa Barat penting untuk dikaji. Urgensi ini diperkuat dengan kehidupan nelayan Indonesia di tengah kondisi degradasi sumberdaya laut yang semakin menurun, kondisi kemiskinan absolut yang dihadapi oleh nelayan artisanal dan semakin kompleksnya persoalan pemanfaatan sumberdaya 
pesisir di Indonesia dengan semakin beragamnya stakeholder pemanfaat sumberdaya tersebut.

Kajian teoritis yang menjelaskan bagaimana dampak sikap terhadap perilaku individu telah dibahas sejak tahun 1862. Dalam kurun waktu tahun 1918 hingga 1925 para ahli psikologi sosial telah memunculkan berbagai teori yang menghubungkan antara sikap dengan perilaku. Tesis utama dari perkembangan perspektif teori tersebut adalah "sikap dapat menjelaskan perilaku individu” (Ajzen \& Fishbein, 1980). Berangkat dari kritik terhadap teori dan pengukuran sikap yang seringkali tidak tepat, yaitu tidak dapat memperkirakan perilaku yang akan timbul, Fishbein (1967) dan Ajzen (Fishbein \& Ajzen, 1975) memunculkan pentingnya unsur "niat untuk berperilaku". Menurut Fishbein \& Ajzen, (1975), mengukur sikap terhadap niat sama bengan mengukur perilaku itu sendiri karena menurut mereka hubungan antara niat dan perilaku adalah yang paling dekat. Perspektif teori yang kemudian dikenal dengan nama Theory Planned Behaviorini selanjutnya digunakan oleh banyak peneliti untuk memperkirakan perilaku (behavior) melalui niat untuk berperilaku (behavior intention) (Beedell \& Rehman (2000), (Moorrison, 2002), (Arifin, 1995), (Sean Charlene, 2001), (Mark Conner, 2002), (Mark A, Elliot, 2003), (Carey, 2007), (Ginis Martin, 2007), (Ryan J, Martin, 2010) dan sebagainya.

Dalam berbagai literatur Berkes et al., (2001), Charles (2001), Satria (2002), Johnson (2005), Luky (2007) nelayan artisanal yang termasuk sebagai small scale fishery adalah orang pemilik perahu yang tergantung sebagian besar penghasilannya pada kegiatan penangkapan ikan di laut, mengoperasikan sendiri perahunya, dengan menggunakan peralatan tangkap ikan sederhana (seperti gilnet, jaring badut, minitrawl, pancing, rawai pancing), ukuran berat perahu antara 2,75-25 GT (atau ukuran panjang perahu antara 5 meter hingga 15 meter, lebar antara 1,5 meter hingga 6 meter), menggunakan sistem penghasilan bagi hasil antara pemilik dan anak buah kapal, hasil tangkapan ikan dijual dalam lingkup pasar lokal yang terbatas. Di Indonesia masyarakat nelayan merupakan salah satu golongan masyarakat yang dianggap miskin secara absolut, bahkan paling miskin diantara penduduk miskin (the poorest of the poot) (Mukflihati, 2010). Berbagai studi juga telah menunjukkan kondisi nelayan khususnya nelayan small scale fishery di Indonesia berada pada tingkat marjinal (Kusnadi (2000) Semedi (2003), Budi (2008).

Berbagai upaya telah dilakukan oleh pemerintah untuk meningkatkan kualitas hidup nelayan, meskipun dalam implementasinya kebijakan yang dikeluarkan pemerintah selalu tidak berpihak kepada nelayan atau lemahnya penerapan hukum regulasi tersebut. Kebijakan yang telah dikeluarkan pemerintah dimulai dari keluarnya kebijakan Revolusi Biru sejak tahun 1970-an hingga regulasi di tingkat undang-undang pada saat ini. Bila di bidang pertanian pada saat yang sama pemerintah mengeluarkan kebijakan Revolusi Hijau dalam rangka modernisasi sistem pertanian untuk dapat meningkatkan tingkat kesejahteraan petani, Revolusi Biru dikeluarkan oleh pemerintah sebagai kebijakan politik perikanan yang pada awalnya ingin mengikuti success story di bidang pertanian. Target Revolusi Biru adalah peningkatan kesejahteraan nelayan melalui upaya peningkatan efisiensi dan produktifitas perikanan khususnya sumberdaya laut dengan berbagai varian kebijakan mulai dari modernisasi penggunaan motorisasi dan teknologi alat tangkap yang modern; kebijakan pembe-rian fasilitas kredit berupa kredit usaha, mesin-mesin, perahu-perahu dan peralatan penting kepada nelayan; pembangunan fasilitas infrastruktur yang mendukung kegiatan perikanan agar menjamin efektivitas dan peningkatan produksi berupa pelabuhan perikanan, ruang pendingin, tempat pengeringan ikan dan pelelangan ikan (TPI). Pada tahun 1980 - 1996 kebijakan ini diperbaharui dengan diluncurkannya deregulasi perikanan yang mencakup pengembangan alat tangkap, pembangunan pelabuhan dan penambahan armada penangkapan ikan melalui kemampuan produksi dalam negeri maupun impor kapal bekas serta pemberian izin kapal asing.

Dampak kebijakan Revolusi Biru yang dikeluarkan pemerintah memang cukup fantastis yakni sejak tahun 1970 hingga 2003 terjadi peningkatan produksi perikanan baik perikanan tangkap maupun budidaya. Hal ini dikarenakan Revolusi Biru yang didukung aktifitas usaha berskala besar dan padat modal menjustifikasi adanya penetrasi kapitalisme yang tidak berbasis pada kemandirian nelayan kecil dan petani ikan. Secara khusus ada enam implikasi yang muncul akibat dari perkembangan ini (Tridoyo, 2004). Pertama, degradasi sumberdaya ikan, penurunan daya dukung lingkungan laut dan kerusakan ekosistem; kedua, menciptakan ketimpangan kelas yang lebar antara pemilik kapal dan buruh nelayan; ketiga, degradasi hutan mangrove dan pengalihan lahan tambak kepada pemodal; keempat, konflik ruang di wilayah pesisir 
yang disebabkan oleh wilayah kegiatan perikanan, pelabuhan, pariwisata, industri maupun kawasan konservasi; kelima, rendahnya kapasitas sumberdaya manusia nelayan sehingga produktifitas mereka juga rendah; dan keenam ketidakadilan struktural yang merugikan nelayan miskin dalam keterbatasan akses modal.

Upaya lain yang telah dilakukan oleh pemerintah untuk meningkatkan kualitas hidup nelayan diantaranya melaluiprogrampenyalurankreditusahakepadanelayan, bantuan subsidi bahan bakar minyak (BBM), Keputusan Menteri Pertanian No.607.Kpts/Um/9/1976 tentang pembagian wilayah penangkapan berdasarkan tingkat kualifikasi peralatan tangkap yang dimiliki oleh nelayan, Keppres No.39/1980 tentang penghapusan operasi kapal pukat harimau, Undang-undang Nomor 27 Tahun 2007 tentang Pengelolaan Wilayah Pesisir dan Pulaupulau Kecil serta lahirnya Keputusan Presiden Nomor 10 Tahun 2011 tentang Tim Koordinasi Peningkatan dan Perluasan Program Pro Rakyat yang mengalokasikan dana sebsar Rp.927,82 milyar untuk mensejahterakan nelayan. Dalam kenyataannya penegakkan regulasi dan implementasi program-program tersebut hingga saat ini sangat lemah dan mengindikasikan seolah-olah regulasi dan kebijakan tersebut tidak pernah ada sebagaimana stagnasi peningkatan kesejahteraan hidup nelayan. Ujungnya, pengalokasian sumberdaya dan sumberdana dalam sistem perikanan perikanan tangkap bagi nelayan kecil masih jauh dari kondisi yang dapat meningkatkan kualitas hidup nelayan.

Sistem kegiatan perikanan tangkap nelayan artisanal terdiri dari 4 (empat) aspek kegiatan (Kusnadi, 2001), Charles (2001) yaitu (a) kegiatan dalan bidang penggunaan teknologi alat tangkap dan alat bantu tangkap berkait dengan capital dynamicsyaitu armada, alat tangkap (fleer) dan alat bantu tangkap yang mendorong hasil tangkapan maksimal dengan dampak seminimal mungkin terhadap lingkungan fisik; (b) kegiatan dalam bidang kegiatan persiapan dan operasi penangkapan yang berisi tentang kemampuan nelayan menentukan waktu musim ikan, lokasi penangkapan ikan, ukuran dan jenis ikan yang boleh ditangkap serta kondisi cuaca yang memungkinkan untuk melaut; (c) kegiatan dalam bidang pengerahan tenaga kerja dan modal yang berisi tentang kemampuan nelayan untuk mengoptimalkan tenaga kerja dan modal yang ada dalam mengoperasikan perahu beserta alat tangkap; dan (d) kegiatan dalam bidang menjaga mutu hasil tangkapan dan pemasaran ikan berkait dengan kemampuan nelayan mengupayakan mutu ikan yang baik tetap terjaga untuk mencapai harga jual ikan yang setinggi-tingginya.

Merujuk kepada perspektif Theory Planned Behavior(Ajzen, 2005) yang menempatkan komponen sikap (attitude), norma subjektif (subjectif norm) dan keyakinan kemampuan berperilaku (perceived behaviour contro\ sebagai aspek yang mempengaruhi niat untuk berperilaku (behaviour intention) untuk memperkirakan perilaku (behaviour), maka penelitian ini bertujuan untuk menguji keberlakukan perspektif Theory Planned Behaviorpada masyarakat nelayan di pantai Utara Provinsi Jawa Barat. Pengujian perspektif teori ini dilakukan dengan cara (1) menemukan faktorfaktor yang berpengaruh pada niat untuk berperilaku nelayan artisanal dalam memanfaatkan sumberdaya pesisir; (2) mengetahui berapa besar pengaruh faktor niat untuk berperilaku tersebut terhadap perilaku nelayan artisanal dalam memanfaatkan sumberdaya; dan (3) mengetahui berapa besar pengaruh faktor latar belakang berupa karakterisik demografi terhadap sikap (attitude), norma subjektif (subjective norm) dan keyakinan kemampuan berperilaku (perceived behavior controð pada nelayan di pantai Utara Provinsi Jawa Barat.

\section{Metode Penelitian}

Penelitian ini merupakan penelitian deskriptif ex post pacto yaitu penelitian mengukur perilaku dengan menanyakan peristiwa yang telah terjadi. Penelitian ini dilakukan di 16 desa, 11 wilayah kecamatan yang tersebar dalam 5 wilayah kabupaten di pantai Utara Provinsi Jawa Barat. Kelima kebupaten tersebut adalah kabupaten Cirebon, Indramayu, Subang, Karawang dan Bekasi. Unit pengamatan terkecil yang diamati pada penelitian ini adalah rumah tangga nelayan artisanal pemilik perahu yang mengoperasikan sendiri perahunya di wilayah desa-desa pesisir terpilih. Jumlah rumah tangga nelayan artisanal di desa-desa pantai Utara Provinsi Jawa Barat seluruhnya 10.404 KK. Penentuan jumlah sampel mengacu pada rumus Slovin dengan tingkat kesalahan sebesar 5\%, yaitu 400 rumah tangga.

Data yang terkumpul merupakan data primer yang mencakup karakteristik demografi, sikap, norma subjektif, keyakinan kemampuan berperilaku, niat untuk berperilaku dan perilaku nelayan dalam kegiatan 
perikanan tangkap. Data ini diperoleh dengan melalui wawancara dengan menggunakan instrumen kuesioner. Pengolahan data dilakukan menggunakan SPSS for Windows dan Lisrel 8.54. Analisis data dibedakan atas analisis deskriptif dan analisis inferensial. Analisis statistik inferensial yang digunakan adalah Structural Equation Model(SEM). Pengujian kesesuaian model dilakukan dengan menggunakan beberapa ukuran model GFT ( Goodness of Fit Tes $x$ ). Menurut Kusnendi (2008), suatu model struktural diindikasikan sesuai atau fit bila memenuhi tiga jenis GFT, yaitu (1) Uji khi kuadrat dengan $p$-value $\geq 0,05$; (2) RMSEA (Root Means Square Error of Approximation) $\leq 0,08$ dan (3) CFI (Comparative Fit Indeks) $\geq 0,90$.

Enam peubah dengan 57 indikator dijabarkan dalam hubungan antar peubah tersebut. Keenam variebal tersebut adalah Karaktersitik Individu (X1), Sikap/Attitude, Norma Subjektif / Subjective Norm (X3), Keyakinan Kemampuan Berperilaku/ Perceived Bahavior Control (X4), Niat untuk Berperilaku/Behavior Intention (Y1) dan Perilaku/ Behavior(Y2).

\section{Hasil dan Pembahasan}

\section{Profil Umum Nelayan Artisanal di Pantai Utara Provinsi Jawa Barat}

Profil umum responden nelayan artisanal di pantai Utara Provinsi Jawa Barat. Usia nelayan artisanal di pantai Utara Provinsi Jawa Barat berkisar antara 30-55 tahun dengan rataan usia nelayan di kabupaten Cirebon 46,4 tahun, Indramayu 46,8 tahun, Subang 48,3 tahun, Karawang 47,2 tahun dan kabupaten Bekasi 45,6 tahun. Kondisi demikian tidak jauh berbeda dengan hasil penelitian Muflikhati (2010) yang melihat karakteristik usia nelayan di pesisir pantai Utara dan Selatan Jawa Barat. Penelitian tersebut melihat usia ayah sebagai kepala keluarga nelayan, yang berada pada rataan usia 43,1 tahun.

Pekerjaan sebagai nelayan berada de-ngan rataan usia berada pada 46,8 tahun dengan banyaknya jumlah jiwa yang harus ditanggung oleh nelayan dalam satu rumah tangga. Nelayan di wilayah kebupaten Bekasi, harus menanggung 4,6 jiwa dalam setiap rumah tangga tidak termasuk dirinya. Nelayan kabupaten Karawang harus menanggung hidup ratarata 4,7 jiwa, kabupaten Subang 4,8 jiwa, kabupaten Indramayu 4,6 jiwa dan kabupaten Cirebon 4,6 jiwa.
Bila jumlah nelayan artisanal di wilayah pantai Utara Jawa Barat seluruhnya 10.404 jiwa, maka total jumlah jiwa yang tergantung dari nelayan tersebut mencapai tidak kurang dari 40.000. Belum lagi jumlah jiwa yang terdapat dalam rumah tangga nelayan buruh (anak buah kapal) dan rumah tangga yang bergantung sepenuhnya pada sektor perikanan lainnya seperti pelelangan ikan, pengolahan ikan, bengkel perbaikan dan penjualan perahu dan mesin.

Tingginya jumlah jiwa dalam rumah tangga nelayan artisanal yang tergantung terhadap ketersediaan sumberdaya perikanan di pantai Utara Provinsi Jawa Barat, di sisi lain ternyata diiringi dengan semakin tingginya degradasi sumberdaya perikanan setempat. Hasil penelitian LIPI pada tahun 2005 mencatat bahwa sumberdaya ikan demersal di pantai Utara Jawa dieksplotasi dengan cepat setelah indroduksi alat tangkap trawl pada akhir tahun 1960. Perkembangan alat tangkap tersebut merupakan penyebab utama penurunan stok ikan demersal. Sementara itu ketersedian sumberdaya ikan pelagis telah lama dieksploitasi oleh berbagai alat tangkap diantaranya seperti jaring payang. Suatu kenyataan dihadapi bahwa perairan pesisir Utara Jawa sudah menderita kejenuhan bagi usaha perikanan. Kondisi ini diperparah dengan jumlah perahu motor dan nelayan yang tidak sebanding dengan potensi perikanan yang tersedia. Temuan tersebut sejalan dengan hasil penelitian Semedi (2003) yang mencatat angka penurunan hasil tangkapan nelayan yang disebabkan oleh over fishingdi pantai Utara Jawa sejak tahun 1980an. Bagi nelayan yang memiliki modal seperti nelayan purseine, kejenuhan wilayah tangkap di pantai Utara Jawa mereka dialihkan dengan mencari wilayah tangkap yang masih memiliki potensi ikan hingga kepulauan Natuna, propinsi Kepulauan Riau.

Dalam berbagai literatur temuan hasil penelitian, tingkat pendidikan nelayan umumnya rendah. Penelitian Muflikhati (2010) mencatat bahwa rataan lama nelayan mengikuti pendidikian formal berada pada angka 4,63 tahun yang berarti tidak mencapai kelas 5 Sekolah Dasar. Hal ini berarti nelayan tersebut rata-rata hanya mengecap tingkat pendidikan maksimal hingga kelas 5 Sekolah Dasar. Minimnya tingkat raihan nelayan terhadap akses pendidikan formal ternyata tidak berbeda dengan kondisi nelayan ketika mereka mengakses jenis pendidikan non formal seperti dalam bentuk kursus, magang atau pelatihan. Nelayan artisanal di kabupaten Cirebon misalnya, rata-rata hanya dapat mengakses pendidikan non formal selama 4,9 jam per tahun, 
sementara itu nelayan di kabupaten Subang 3,5 jam per tahun, Indramayu 5,8 jam per tahun, kabupaten Karawang 4,3 jam per tahun dan nelayan di kabupaten Bekasi 4,8 jam per tahun.

Rendahnya capaian tingkat pendidikan formal dan non formal nelayan di pantai Utara Provinsi Jawa Barat ternyata tidak seluruhnya sejalan dengan kriteria tingkat kemiskinan yang menggunakan indikator pemasukan dan pengeluaran. Penelitian Muflikhati (2010) bahwa jika kesejahteraan nelayan hanya diukur dengan ukuran ekonomi (pendapatan dan pengeluaran), maka keluarga nelayan dapat dikatakan lebih sejahtera daripada keluarga bukan nelayan. Namun dengan indikator yang memiliki dimensi lebih luas dan lebih menjelaskan kondisi kehidupan dari berbagai aspek seperti akses terhadap pendidikan, terlihat bahwa keluarga nelayan berada dalam kondisi rendah dalam tingkat kesejahteraannya.

Rendahnya tingkat pendidikan formal dan non formal yang dapat diakses oleh nelayan artisanal pantau Utara Jawa Barat, tidak menjadikan sulitnya mereka dapat menguasai teknik-teknik dalam kegiatan perikanan tangkap. Proses sosialisasi dan enkulturasi yang dilakukan oleh nelayan secara turun temurun, menjadikan pengetahuan kemampuan melaut dan menangkap ikan dapat tersampaikan antar generasi. Bagi seorang individu nelayan, proses tersebut tidak berjalan secara singkat, melainkan berlangsung hingga puluhan tahun. Temuan penelitian ini menunjukkan rata-rata lama responden bekerja menjadi nelayan yang mencapai hingga 21,28 tahun. Demikian pula dengan lamanya waktu telah memiliki perahu secara sendiri rata-rata sudah mencapai waktu 17,26 tahun.

Nelayan artisanal di pantai Utara Provinsi Jawa Barat, merupakan contoh nelayan yang sulit memperoleh pekerjaan lain diluar sektor kenelayanan. Bagi nelayan yang tinggal di wilayah pesisir dengan kondisi sumberdaya alam yang masih tersedia, diversifikasi dimungkinkan ke bidang pekerjaan lain ketika untuk sementara bidang pekerjaan nelayan tidak menghasilkan pendapatan yang cukup. Nelayan di pulau Ranai Natuna di kepulauan Riau, misalnya. Manakala mereka tidak bisa melaut karena keadaan cuaca yang buruk, mereka dapat menjadi petani sayuran atau petani perkebunan kelapa yang ada di wilayah mereka. Pada daerah yang sumberdaya alamnya sulit seperti pesisir pantai Utara Provinsi Jawa Barat, diversifikasi pekerjaan sulit dilakukan kecuali mereka melakukan konversi pekerjaan di bidang lain, misalnya menarik becak atau menjadi buruh bangunan. Selain terhambat oleh keterbatasan sumberdaya ekonomi, konversi pekerjaan juga sulit dilakukan karena terhambat oleh aspek sosiokutural yang sangat terikat dengan pekerjaan sebagai nelayan. Lamanya masa bekerja sebagai nelayan menyebabkan diversifikasi pekerjaan ke bidang lain riskan untuk mereka lakukan, meskipun pekerjaan sebagai nelayan tidak memberikan hasil yang teratur dan stabil. Bagi nelayan artisanal di pantai Utara Provinsi Jawa Barat, laut sudah menjadi "sawah" mereka untuk bermatapencaharian. Pengetahuan yang mereka miliki tentang laut, tidak sekedar hamparan air yang luas namun sudah merupakan petak-petak wilayah yang masing-masing merupakan wilayah "desa-desa ikan" sebagai wilayah tangkap (fishing ground). Contoh "desa-desa ikan" sebagai fishing ground yang dikenal seperti karang gosong, kelip pertamina dan lain-lain yang merupakan wilayah tangkap favorit nelayan sebagai wilayah fishing ground.

Nelayan artisanal di pantai Utara Provinsi Jawa Barat umumnya merupakan nelayan dengan ukuran perahu relatif kecil dengan indeks luas perahu antara 3-71 M2. Secara tersebar rataan ukuran indeks luas perahu nelayan masing-masing kabupaten adalah Cirebon 13,2 M2, Indramayu 18,2 M2, Subang 17,8 M2, Karawang 17,3 M2 dan kabupaten Bekasi 14,5 M2. Sebagai konsekuensi logis dari ukuran perahu yang relatif kecil adalah rendahnya daya jangkau kegiatan melaut mereka. Keterbatasan ini disiasati dengan kegiatan melaut dalam bentuk one day fishing, yaitu berangkat melaut pada sore hari dan kembali esok harinya. Strategi lain dalam menghadapi persoalan terbatasnya jangkauan melaut adalah dengan melakukan andun yakni mencari fishing ground di wilayah kabupaten lain sebelah Barat atau Timur untuk sementara waktu bila di wilayah mereka sedang tidak musim ikan atau tidak memungkinkan untuk melaut karena kondisi cuaca yang buruk.

Tradisi menjadi nelayan andun, juga dilakukan oleh nelayan artisanal pantai Utara Provinsi Jawa Barat. Beberapa penelitian menunjukkan adanya tradisi andun terutama dilakukan pada wilayah pesisir yang terbatas sumberdaya alamnya. Penelitian Kusnadi (2002) mencatat nelayan di pantai Utara Provinsi Jawa Timur senantiasa melakukan tradisi andun ke wilayah kabupaten lain di Jawa Timur yang sedang musim ikan, atau pada saat kondisi cuaca tidak memungkinkan untuk melaut di wilayah kabupaten 


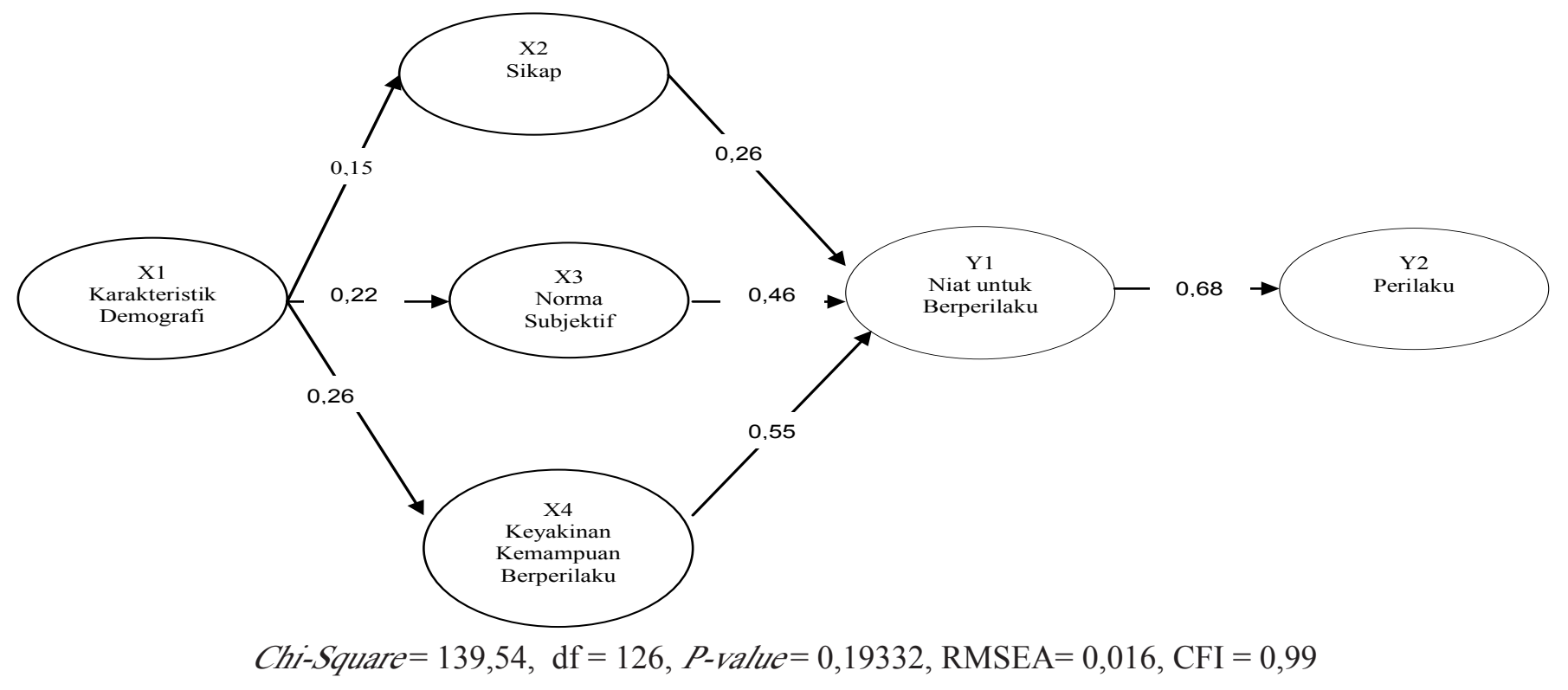

Gambar 1 Hubungan antar Peubah tentang Faktor-faktor yang Mempengaruhi Perilaku Nelayan dengan Perspektif Theory Planned Behavior

asal mereka. Keadaan ini berbeda dengan nelayan yang berada di wilayah dengan sumberdaya alam masih baik. Bila tidak memungkinkan nelayan untuk melaut karena tidak musim ikan atau kondisi cuaca yang buruk, mereka melakukan diversifikasi sementara ke bidang pekerjaan lain seperti bertani. Bagi nelayan pantai Utara Provinsi Jawa Barat, tradisi andun mereka lakukan ke wilayah kabupaten sekitarnya hingga ke Muara Angke Jakarta dan Banten. Waktu pelaksanaan andun dapat mencapai 8 bulan atau hingga lepas musim ikan. Salah satu strategi yang dilakukan nelayan karena keterbatasan ukuran perahu dan jangkauan wilayah tangkap adalah dengan melakukan andun.

Strategi lain yang dilakukan oleh nelayan artisanal di pantau Utara Provinsi Jawa Barat dalam hal pengadaan modal melaut adalah dengan meminjamkepada punggawa yang sekaligus bertindak sebagai pedagang perantara. Betapa tinggi tingkat ketergantungan nelayan terhadap punggawa, tidak hanya dari sisi pengadaan modal melaut yang ratarata dalam satu bulan meminjam hingga $16-17$ kali, namun dalam hal pengambilan keputusan kegiatan perikanan sebagian besar dari nelayan tergantung pada mereka (significant other). Fenomena hubungan patronklien nelayan dengan punggawa pemilik modal sekaligus sebagai pedagang perantara ini teridentifikasi pada banyak literatur hasil penelitian nelayan di Indonesia (Kusnadi, 2002; Semedi, 2002; Siswanto, 2008). Pada posisi demikian, nelayan berperan sebagai alat produksi modal dari punggawa untuk menjamin tersedianya stok ikan yang mereka jual. Karena ikatan hutang antara nelayan terhadap punggawa, maka nelayan harus menjual ikan hasil tangkapan kepada punggawa yang memodalinya melaut dengan harga yang ditentukan oleh punggawa. Di sisi lain kondisi demikian tidak didukung oleh institusi perdagangan ikan yang berpihak kepada nelayan. Dari Tempat Pelelangan Ikan (TPI) yang terdapat di pantai Utara Provinsi Jawa Barat seperti Cirebon, Indramayu, Subang, Karawang dan Bekasi; institusi TPI pada umumnya tidak berjalan seperti yang diharapkan meskipun telah ada regulasi yang mewajibkan untuk menjual ikan melalui sistem lelang di TPI. Perda Nomor 5 Tahun 2005 yang dikeluarkan oleh Pemda Kabupaten Indramayu merupakan salah satu contoh regulasi kewajiban menjual ikan hasil tangkapan di laut melalui institusi lelang di TPI. Namun demikian regulasi ini hanya semata menjadi instrumen bagi retribusi dana lelang kepada Pemda melalui TPI. Kecenderungan yang terjadi pada semua wilayah kabupaten adalah pembelian langsung ikan dari nelayan kepada punggawa yang memodalinya asalkan punggawa membayar retribusi kepada TPI setempat. Tidak sedikit pula kasus yang terjadi yaitu pembelian langsung ikan dari nelayan ke punggawa tanpa melalui retribusi lelang ke TPI.

\section{Pengujian Hipotesis}

Gambaran hubungan antar peubah tentang 
faktor-faktor yang mempengaruhi perilaku nelayan artisanal dalam kegiatan perikanan tangkap di pantai Utara Provinsi Jawa Barat dijabarkan dalam gambar 1 berikut:

Hipotesis 1: Karakteristik Demografi berpengaruh positif terhadap Sikap (X2).

Gambar 1 menunjukkan adanya pengaruh langsung peubah karakteristik terhadap sikap nelayan sebesar 0,15 yang nyata pada $\alpha=0,05$. Persamaan matematik model struktural sikap nelayan adalah $\mathrm{X} 2=0,15 \mathrm{X} 1$. Maka hipotesis 1 diterima.

Hipotesis 2: Karaktersitik Demografi X1) berpengaruh positif terhadap Norma Subjektif (X3).

Gambar 1 menunjukkan adanya pengaruh langsung peubah karakteristik terhadap norma subjektif nelayan sebesar 0,22 yang nyata pada $\alpha=$ 0,05 . Persamaan matematik model struktural sikap nelayan adalah $\mathrm{X} 3=0,22 \mathrm{X} 1$. Maka hipotesis 2 diterima.

Hipotesis 3: Karaktersitik Demografi (X1) berpengaruh positif terhadap Keyakinan Kemampuan Berperilaku (X4).

Gambar 1 menunjukkan adanya pengaruh langsung peubah karakteristik terhadap keyakinan kemampuan berperilaku sebesar 0,26 yang nyata pada $\alpha=0,05$. Persamaan matematik model struktural sikap nelayan adalah X4 $=0,26$ X1. Maka hipotesis 3 diterima.

Hipotesis 4: Sikap (X2), Norma Subjektif (X3) dan Keyakinan Kemampuan Berperilaku (X4) berpengaruh positif terhadap Niat untuk Berperilaku (Y1).

Gambar 1 menunjukkan adanya pengaruh langsung peubah sikap, norma subkektif dan keyakinan kemampuan berperilaku terhadap niat untuk berperilaku masing-masing secara berturutturut sebesar 0,$26 ; 0,46$ dan 0,55 yang nyata pada $\alpha$ $=0,05$. Persamaan matematik model struktural niat untuk berperilaku adalah Y1 $=0,26 \mathrm{X} 2+0,46 \mathrm{X} 3$ $+0,55 X 4$. Secara bersama pengaruh ketiga peubah (X2; X3 dan X4) pada niat untuk berperilaku nelayan sebesar 64 persen yang nyata pada $\alpha=0,05$. Maka hipotesis 4 diterima.
Hipotesis 5: Niat untuk Berperilaku

berpengaruh positif terhadap Perilaku.

Gambar 1 menunjukkan pengaruh peubah niat untuk berperilaku terhadap perilaku nelayan sebesar 0,68 . Secara matematik persa-maan model struktural perilaku nelayan adalah Y2 $=0,68 \mathrm{Y} 1$. Pengaruh niat untuk berperilaku pada perilaku koefisien determinasinya sebesar $47 \%$, sisanya 53 persen merupakan pengaruh peubah lain di luar penelitian ini. Maka hipotesis 5 diterima.

\section{Pengaruh Karakteristik terhadap Sikap}

Hasil penelitian menunjukkan bahwa peubah karakteristik demografi berpengaruh secara nyata terhadap sikap dalam kegiatan perikanan tangkap. Kondisi ini menunjukkan bila peubah karakteristik ikut menentukan sikap positif nelayan dengan koefisien pengaruh sebesar 0,15 yang nyata pada $\alpha=0,05$. Indikasi dari situasi tersebut, jika terjadi peningkatan satu satuan karakteristik nelayan selanjutnya akan meningkatkan sikap positif nelayan dalam penggunaan alat tangkap sebesar 0,54 satuan, sikap positif dalam melakukan operasi kegiatan penangkapan sebesar 0,54 satuan dan sikap positif dalam menjaga mutu ikan hasil tangkapan sebesar 0,59 satuan. Pengaruh nyata peubah karakteristik terhadap peubah sikap disebabkan oleh dimensi besaran ukuran perahu yang dimiliki, jumlah anak buah kapal dan besaran ukuran mesin perahu.

Temuan penelitian ini bahwa besaran ukuran perahu yang dinyatakan dalam bentuk indeks luas perahu nelayan di pantai Utara Provinsi Jawa Barat menunjukkan rata-rata ukuran perahu berada pada perahu ukuran kecil yaitu antara 13,2-18,2 $\mathrm{M}^{2}$., bila melihat rentang ukuran indeks luas perahu di kabupaten Cirebon, Indramayu, Subang, Karawang dan Bekasi yang berada antara $3-72 \mathrm{M}^{2}$. Sementara itu rata-rata jumlah anak buah kapal yang dimiliki oleh nelayan adalah 5,7 jiwa yang berada pada rentang antara 1 - 19 anak buah kapal. Banyaknya anak buah kapal tergantung dari ukuran perahu yang mereka miliki. Pada perahu berukuran kecil seperti yang sebagian besar dimiliki oleh nelayan artisanal di pantai Utara Provinsi Jawa Barat yakni antara 13,2 - 18,2 $\mathrm{M}^{2}$, maka jumlah anak buah kapal antara $1-6$ anak buah kapal, sementara itu untuk ukuran perahu besar seperti purseseine jumlah anak buah kapal dapat mencapai 19 orang. Untuk besaran ukuran mesin perahu yang dinyatakan dalam bentuk PK ( Pärk de Kräcr) atau HP 
(Horse Power), maka rata-rata perahu nelayan memiliki mesin berkekuatan 34,4 PK yang berada rentang antara 2 - 120 PK atau sebanyak 71,2\% memiliki kekuatan mesin perahu rendah $<20 \mathrm{PK}$.

Bagi nelayan pantai Utara Provinsi Jawa Barat, sebagian besar $(83,5 \%)$ dari mereka hanya memiliki ukuran indeks luas perahu maksimal sebesar $3 \mathrm{M}^{2}$ hingga $26 \mathrm{M}^{2}$ dan hanya sebagian kecil $(3,0 \%)$ yang menggunakan perahu berukuran luas antara $50 \mathrm{M}^{2}$ hingga $72 \mathrm{M}^{2}$ (ukuran kapal pursesine). Semakin besar ukuran indeks luas perahu yang dimiliki oleh nelayan, berarti semakin besar pula resiko ekonomi yang harus ditanggung mereka sehingga harus semakin positif sikap mereka dalam melakukan kegiatan penangkapan ikan untuk memperkecil resiko ekonomi yang telah dikeluarkan sebagai salah satu modal usaha. Sumbersumber permodalan nelayan artisanal di pantai Utara Provinsi Jawa Barat diantaranya adalah tabungan dan harta benda pribadi, pinjaman dari kerabat dan tetangga serta pinjaman dari tengkulak (pedagang ikan perantara). Kondisi tersebut juga terjadi pada nelayan pantai Utara Jawa Timur (selat Madura) (Kusnadi, 2000). Pelibatan pihak lain seperti pinjaman dari kerabat dan tengkulak, aset dan tabungan pribadi nelayan sebagai modal usaha kegiatan perikanan untuk pengadaan perahu, merupakan tekanan tersendiri bagi nelayan untuk menjaga agar modal yang telah dikeluarkan tidak hilang karena merugi.

Jumlah nelayan artisanal yang memiliki anak buahkapal pada perahuyang dioperasikannyasebagian besar $(57,2 \%)$ antara 1 hingga 6 orang. Pelibatan anak buah kapal pada kegiatan nelayan artisanal umumnya merupakan pelibatan yang didasarkan atas prinsip ketrampilan dan hubungan kerabat diantara mereka dengan bertujuan untuk memberikan kontribusi secara ekonomi. Semakin besar jumlah anak buah kapal yang dimiliki oleh seorang nelayan artisanal pemilik, semakin besar tanggungjawabnya dalam kontribusi ekonomi terhadap para anak buah kapal dan anggota keluarga yang menjadi tanggungannya. Kenyataan ini lebih diperkuat dengan keadaan sebanyak 70,2\% nelayan artisanal di pantai Utara Provinsi Jawa Barat harus menanggung secara ekonomi 4 hingga 5 anggota keluarga. Seorang nelayan artisanal pemilik perahu, dalam hubungan patron klien memiliki tanggungjawab sosial terhadap anak buah kapal yang menjadi kliennya. Penelitian Siswanto (2008), Kusnadi (2000) mengindikasikan bentuk-bentuk tanggung jawab sosial dan ekonomi nelayan pemilik terhadap anak buah kapalnya. Di saat anak buah kapal mengalami kesulitan di bidang ekonomi, pihak pertama yang didatangi untuk dimintakan bantuan adalah juragan pemilik kapal. Melihat kenyataan tersebut, maka banyaknya anak buah kapal yang dimiliki oleh seorang nelayan artisanal berimplikasi terhadap besarnya tanggung jawab sosial dirinya terhadap anak buah tersebut sehingga meningkatkan sikap positif nelayan pemilik dalam melakukan kegiatan perikanan.

Kondisi tersebut tidak berbeda dengan ukuran mesin kapal yang dimiliki oleh nelayan artisanal di pantai Utara Provinsi Jawa Barat. Besarnya ukuran mesin kapal sejalan dengan nilai ekonomi yang harus dikeluarkan oleh nelayan, menyebabkan nelayan harus berupaya memperkecil resiko terhadap kerugian dengan bersikap positif dalam melakukan kegiatan perikanan tangkap. Di pantai Utara Provinsi Jawa Barat, sebagian besar $(71,2 \%)$ nelayan artisanal merupakan nelayan dengan ukuran besaran mesin perahu antara 0 hingga 6 PK. Hasil penelitian ini mengindikasikan karakteristik nelayan yang semakin besar ukuran mesin perahu, akan memberikan kontribusi terhadap sikap positif nelayan dalam melakukan kegiatan perikanan tangkap. Temuan penelitian ini menegaskan bahwa untuk menekan resiko kerugian, maka nelayan artisanal mengembangkan sikap positif khususnya dalam hal penggunaan alat tangkap, melakukan operasi penangkapan dan menjaga mutu ikan hasil tangkapan.

\section{Pengaruh Karakteristik terhadap Norma Subjektif}

Temuan penelitian ini menunjukkan bahwa peubah karakteristik berpengaruh pula secara nyata terhadap norma subjektif nelayan dalam kegiatan perikanan tangkap. Keadaan ini menunjukkan bahwa peubah karakteristik ikut menentukan positifnya norma subjektif nelayan dengan koefisien pengaruh sebesar 0,22 yang nyata pada $\alpha=0,05$. Hal ini mengindikasikan, jika terjadi peningkatan satu satuan karakteristik nelayan, akan meningkatkan norma subjektif nelayan untuk berperilaku positif nelayan hal penggunaan alat tangkap sebesar 0,70 satuan, norma subjektif nelayan untuk berperilaku positif dalam melakukan operasi kegiatan penangkapan perikanan sebesar 0,84 satuan, sekaligus juga akan meningkatkan norma subjektif untuk berperilaku positif dalam menjaga mutu ikan hasil tangkapan yang akan dijual ke pasar sebesar 0,45 
satuan. Pengaruh nyata peubah karakteristik nelayan terhadap norma subjektif nelayan disebabkan oleh dimensi besaran ukuran perahu yang dimiliki, jumlah anak buah kapal dan besaran ukuran mesin perahu yang dimiliki.

Besaran ukuran perahu yang dimiliki oleh nelayan di pantai Utara Provinsi Jawa Barat, sebagian besar $(83,5 \%)$ dari mereka hanya memiliki ukuran luas indeks perahu maksimal sebesar 3 hingga $26 \mathrm{M}^{2}$, hanya sebagian kecil (3,0\%) yang menggunakan perahu berukuran luas antara 50 hingga $72 \mathrm{M}^{2}$ (atau ukuran kapal pursesine). Semakin besar ukuran perahu yang dimiliki oleh nelayan, berarti semakin besar pula resiko ekonomi yang harus ditanggung yang berarti harus semakin positif pula norma subjektif untuk berperilaku positif nelayan yang digunakan sebagai acuan dalam pengambilan keputusan guna memperkecil resiko ekonomi yang telah dikeluarkan terhadap perahunya sebagai salah satu modal usaha.

Jumlah nelayan artisanal yang memiliki anak buah kapal pada perahu yang dioperasikannya di pantai Utara Provinsi Jawa Barat sebagian besar (57,2\%) berjumlah 0 hingga 6 orang. Pelibatan anak buah kapal pada kegiatan nelayan artisanal umumnya merupakan pelibatan yang didasarkan atas prinsip keterampilan dan hubungan kerabat dengan bertujuan untuk memberikan kontribusi secara ekonomi dan sosial diantara mereka. Semakin besar jumlah anak buah kapal yang dimiliki oleh seorang nelayan artisanal pemilik, semakin besar pula tanggungjawabnya dalam bentuk kontribusi ekonomi terhadap para anak buah kapal dan angota keluarga yang menjadi tanggungannya. Kenyataan ini lebih diperkuat dengan pada keadaan sebanyak $70,2 \%$ nelayan artisanal di pantai Utara Provinsi Jawa Barat harus menanggung secara ekonomi 4 hingga 5 anggota keluarga. Besarnya tanggung jawab sosial nelayan artisanal terhadap anak buah kapal, semakin meningkatkan norma subjektif untuk berperilaku positifyan sebagai referensi mereka dalam mengambil keputusan kegiatan di bidang perikanan tangkap.

Keadaan demikian tidak berbeda halnya dengan ukuran mesin kapal yang dimiliki oleh nelayan artisanal di pantai Utara Provinsi Jawa Barat. Besarnya ukuran mesin perahu yang sejalan dengan nilai ekonomi yang harus dikeluarkan oleh nelayan, menyebabkan nelayan harus berupaya memperkecil resiko terhadap kerugian dengan meningkatkan norma subjektif untuk berperilaku positif dalam mengambil keputusan kegiatan perikanan tangkap. Di pantai Utara Provinsi Jawa Barat, sebagian besar (71,2\%) nelayan artisanal merupakan nelayan dengan ukuran besaran mesin perahu antara 0 hingga 20 PK. Hasil penelitian ini mengindikasikan nelayan dengan karaktersitik semakin besar ukuran mesin perahu, akan memberikan kontribusi terhadap semakin tingginya norma subjektif untuk berperilaku positif sebagai acuan nelayan dalam pengambilan keputusan pada kegiatan perikanan tangkap.

\section{Pengaruh Karakteristik terhadap Keyakinan Kemampuan Berperilaku}

Temuan dari penelitian ini menunjukkan bahwa peubah karakteristik berpengaruh pula secara nyata pada keyakinan kemampuan berperilaku dalam kegiatan perikanan tangkap, berarti peubah karakteristik ikut menentukan keyakinan kemampuan berperilaku nelayan untuk dapat berprilaku secara positif dengan koefisien pengaruh sebesar 0,26 yang nyata pada $\alpha=0,05$. Hal ini mengindikasikan, jika terjadi peningkatan satu satuan karakteristik nelayan, akan meningkatkan keyakinan kemampuan berperilaku dalam hal penggunaan alat tangkap sebesar 0,62 satuan, kemampuan berperilaku nelayan dalam menggunakan alat bantu tangkap sebesar 0,63 satuan serta keyakinan kemampuan berperilaku nelayan dalam melakukan persiapan operasi kegiatan penangkapan perikanan sebesar 0,63 satuan. Pengaruh nyata peubah karakteristik nelayan pada keyakinan kemampuan berperilaku disebabkan oleh dimensi besaran ukuran perahu yang dimiliki, jumlah anak buah kapal dan besaran ukuran mesin perahu.

Besaran ukuran perahu yang dimiliki oleh nelayan di pantai Utara Provinsi Jawa Barat tercatat sebagian besar $(83,5 \%)$ dari mereka hanya memiliki ukuran indeks luas perahu maksimal sebesar 3 hingga $26 \mathrm{M}^{2}$, hanya sebagian kecil (3,0\%) yang menggunakan perahu berukuran luas antara 50 hingga $72 \mathrm{M}^{2}$ (atau ukuran kapal pursesine). Semakin besar ukuran perahu yang dimiliki oleh nelayan, semakin besar pula resiko ekonomi yang harus ditanggung yang berarti harus semakin besar keyakinan kemampuan berperilaku nelayan dalam memperkecil resiko ekonomi yang telah dikeluarkan terhadap perahunya sebagai salah satu modal usaha.

Jumlah nelayan artisanal yang memiliki anak buah kapal pada perahu yang dioperasikannya di pantai Utara Provinsi Jawa Barat, sebagian besar $(57,2 \%) 1$ hingga 6 orang. Pelibatan anak buah kapal 


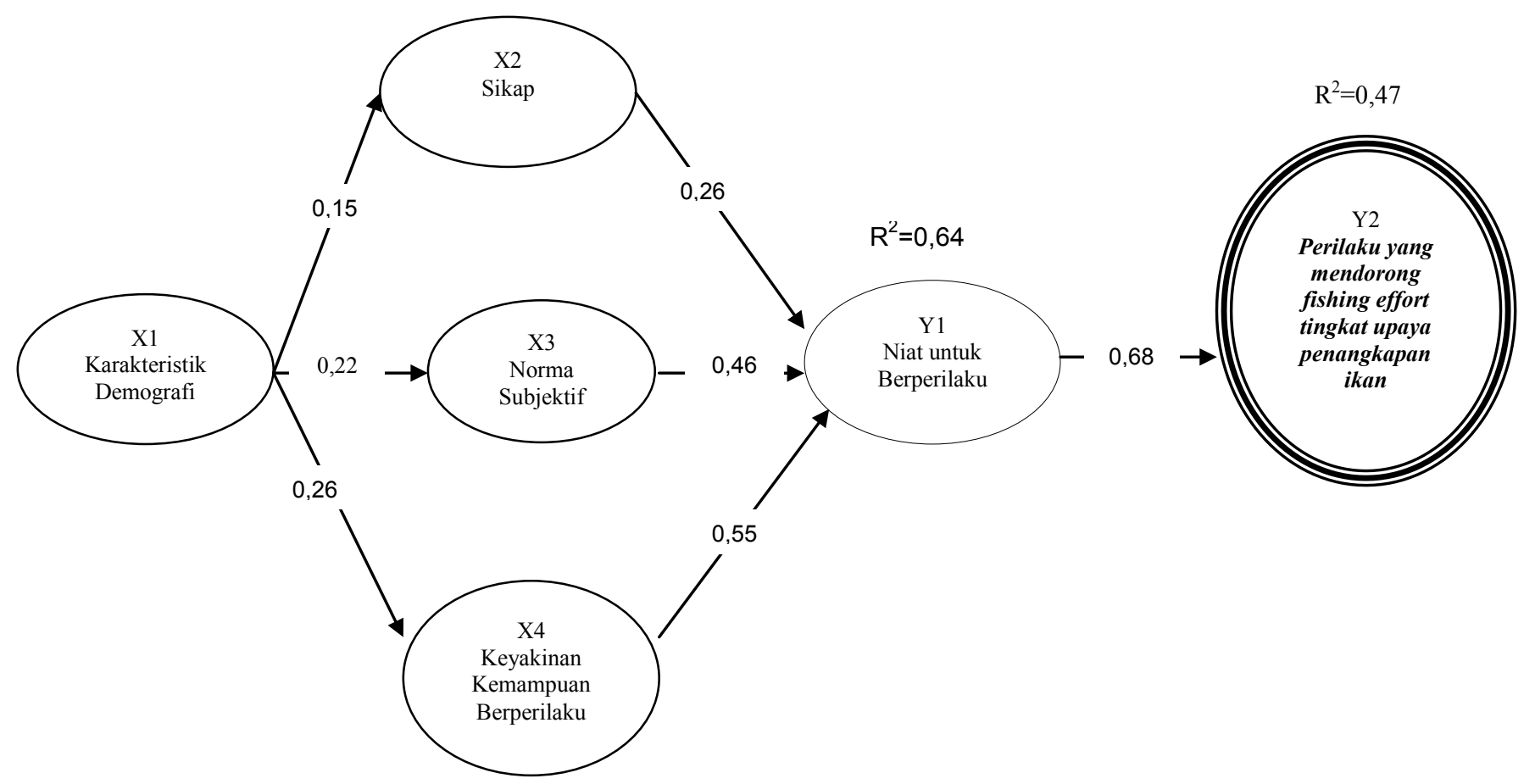

Gambar 2 Kontribusi Theory Planned Behaviorterhadap Persoalan Sifat Kepemilikan Ikan Laut Sebagai Sumber Milik Bersama di Wilayah Studi

pada kegiatan nelayan artisanal umumnya merupakan pelibatan yang didasarkan atas prinsip keterampilan dan hubungan kerabat dengan bertujuan untuk memberikan kontribusi secara sosial dan ekonomi. Semakin besar jumlah anak buah kapal yang dimiliki oleh seorang nelayan artisanal pemilik, semakin besar pula tanggung jawabnya dalam bentuk kontribusi ekonomi terhadap para anak buah kapal dan angota keluarga yang menjadi tanggungannya. Kenyataan ini lebih diperkuat dengan pada keadaan sebanyak 70,2\% nelayan artisanal di pantai Utara Provinsi Jawa Barat harus menanggung secara ekonomi 4 hingga 5 anggota keluarga. Besarnya tanggungjawab ekonomi dan sosial nelayan artisanal terhadap anak buah kapal, semakin meningkatkan persepsi keyakinan akan kemampuan melakukan kegiatan positif dalam kegiatan perikanan.

Keadaan demikian tidak berbeda dengan ukuran mesin kapal yang dimiliki oleh nelayan artisanal di pantai Utara Provinsi Jawa Barat. Besarnya ukuran mesin kapal yang sejalan dengan nilai ekonomi yang harus dikeluarkan oleh nelayan, menyebabkan nelayan harus berupaya memperkecil resiko terhadap kerugian dengan bersikap positif dalam melakukan kegiatan perikanan tangkap. Di pantai Utara Provinsi Jawa Barat, sebagian besar (71,2\%) nelayan artisanal merupakan nelayan dengan ukuran besaran mesin perahu antara 0 hingga 6 PK. Hasil penelitian ini mengindikasikan karakteristik nelayan yang semakin besar ukuran mesin perahu, akan memberikan kontribusi terhadap semakin tingginnya keyakinan kemampuan berperilaku nelayan dalam melakukan kegiatan pada perikanan tangkap.

\section{Pengaruh Sikap, Norma subjektif dan Keyakinan Kemampuan Berperilaku terhadap Niat untuk Berperilaku}

Hasil penelitian menunjukkan bahwa peubah sikap (X2), norma subjektif (X3) dan komptensi (X4) berpengaruh nyata terhadap niat untuk berperilaku (Y1), dengan koefisien determinasi sebesar $64 \%$ yang nyata pada $\alpha=0,05$. Hal ini berarti ketiga peubah X2, $\mathrm{X} 3$ dan $\mathrm{X} 4$ tersebut secara bersama-sama berpengaruh pada niat untuk berperilaku (Y1) sebesar 64\% dan sisanya 36\% merupakan pengaruh peubah lain yang tidak termasuk dalam penelitian ini. Meningkatnya niat untuk berperilaku nelayan nampak dengan semakin positifnya niat untuk berperilaku dalam penggunaan alat tangkap, niat untuk berperilaku pengerahan tenaga kerja dan niat untuk menjaga mutu ikan hasil tangkapan yang akan dipasarkan.

Pengaruh bersama peubah sikap, norma subjektif dan keyakinan kemampuan berperi-laku terhadap niat untuk berperilaku dengan koefisien determinannya sebesar $64 \%$, berarti pengaruh peubah luar sebesar $36 \%$ dalam mempengaruhi niat untuk 
berperilaku nelayan artisanal dalam kegiatan perikanan tangkap. Dengan demikian sikap, norma subjektif dan keyakinan kemampuan berperilaku merupakan faktor yang dominan dalam mempengaruhi niat untuk berperilaku pada kegiatan perikanan tangkap.

\section{Pengaruh Niat untuk Berperilaku terhadap Perilaku}

Temuan penelitian ini menunjukkan bahwa peubah niat untuk berperilaku berpengaruh pula secara nyata terhadap perilaku nelayan dalam kegiatan perikanan tangkap, berarti peubah niat untuk berperilaku ikut menentukan perilaku nelayan secara positif dengan koefisien pengaruh sebesar 0,68 yang nyata pada $\alpha=0,05$. Hal ini mengindikasikan, jika terjadi peningkatan satu satuan niat untuk berperilaku positif nelayan, akan mening-katkan perilaku positif dalam hal penggunaan alat bantu tangkap sebesar 0,56 satuan, perilaku positif dalam melakukan operasi penangkapan sebesar 0,53 satuan serta perilaku positif dalam menjaga mutu ikan hasil tangkapan sebesar 0,62 satuan. Pengaruh nyata peubah niat untuk berperilaku disebabkan oleh dimensi niat untuk berperilaku dalam penggunan alat tangkap, niat untuk berprilaku dalam pengerahan tenaga kerja kegiatan perikanan dan niat untuk berperilaku dalam menjaga mutu ikan yang akan dipasarkan.

\section{Keberlakukan Theory Planned Bahavior dalam Mengukur Perilaku Nelayan di Pantai Utara Provinsi Jawa Barat}

TPB dapat digunakan untuk melihat faktorfaktor yang mempengaruhi perilaku nelayan artisanal dalam pemanfaatan sumberdaya perikanan tangkap di pantai Utara Provinsi Jawa Barat. Temuan penelitian ini juga sejalan dengan temuan penelitian-penelitian lain yang menggunakan perspektif TPB untuk mengukur perilaku (behavior) yang diawali dengan niat untuk berperilaku (behavior intention). Penelitian Beedell dan Rehman (2000) Using Social Psychology Models to Understand Farmers' Conservation Behavior, Moorrison (2002) Teen Sexual Behavior: Application of the Theori Reasoned Action, Arifin (1995) Hubungan Sikap dan Norma Subjektif dengan Intensi Bersanggama pada Mahasiswa di Jakarta, Sean Charlene (2001) Predictor of Intention to Use Condoms Among University Womens: An Apprication and Extention of The Theory Planned
Behavior, Mark, Conner (2002) The TPB and Health Eating, Mark A, Elliot (2003) Driver's Compliance with Speed Limits an Application of the TPB, penelitian Carey, Kate B (2007) The TPB as a Model of Heavy Episodic Drinking Among College Student, Ginis, Martin (2007) Using TPB to Predict Leisure Time PhysicalActivity Kidney Disease, Ryan J, Martin (2010) Using the TPB to Predict Gambling Behavior:

\section{Faktor Lain di Luar Peubah Penelitian}

Nilai R2 peubah perilaku sebesar 0,47 ; mengindikasikan adanya peubah lain di luar peubah penelitian ini sebesar 53\% yang mempengaruhi perilaku Bagaimana mungkin peubah di luar penelitian ini sebesar 53\% dapat mempengaruhi perilaku nelayan? Untuk menjelaskan hal ini, teori strukturasi dapat digunakan sebagai pisau analisis.

Teori strukturasi menjelaskan perbedaan antara agen (dalam tingkat mikro) dan struktur (dalam tingkat makro) (Ritzer, 2004). Agen merujuk kepada kapasitas seseorang untuk bertindak secara independen dan membuat pilihan mereka sendiri. Pada sisi yang lain, struktur secara luas merujuk pada penataan terpolaberulangyangnampaknya mempengaruhi atau membatasi pilihan dan kesempatan yang dimiliki seseorang. Salah satu komponen dari teori strukturasi berupa pemikiran Giddens tentang konsep agen. Dalam upaya mencari rasa aman, agen merasionalisasikan dunia mereka juga membuat mereka menjalani kehidupan sosial seca $\urcorner$ ra efisien. Pada kasus nelayan artisanal di pantai Utara Provinsi Jawa Barat, agen adalah para aktor nelayan artisanal yang memiliki perbedaan latarbelakang karakteristik demografi. Semua tindakan sosial melibatkan struktur, dan semua struktur melibatkan tindakan sosial. Agen dan struktur terjalin erat dalam aktifitas yang terus menerus dijalankan manusia. Struktur dimaksud adalah lingkungan yang memberikan konteks bagi aktor para nelayan dalam berperilaku.

Sejalan dengan konsep agen dan struktur tersebut, penelitian Kusnadi (2000) juga menegaskan adanya faktor-faktor struktur yang menjadikan nelayan tetap menjadi miskin, sebagaimana halnya juga terjadi pada nelayan artisanal di pantai Utara Provinsi Jawa Barat. Faktor-faktor tersebut dapat dikategorikan ke dalam faktor internal (mikro) dan faktor eksternal (makro). Faktor internal adalah faktor-faktor yang berkaitan dengan sumberdaya manusia nelayan dan aktivitas kerja mereka, meliputi: 
(1) keterbatasan kualitas sumberdaya manusia, (2) keterbatasan kemampuan modal usaha dan teknologi penangkapan, (3) hubungan kerja (pemilik perahu nelayan buruh), (4) kesulitan melakukan diversifikasi usaha penangkapan, (5) ketergantungan yang tinggi terhadap okupasi melaut dan (6) gaya hidup hidup yang kurang berorientasi ke depan. Faktor-faktor eksternal adalah faktor-faktor yang berhubungan dengan kondisi di luar diri dan aktivitas kerja nelayan, yang meliputi: (1) masalah kebijakan pembangunan yang lebih berorientasi pada produktivitas untuk menunjang pertumbuhan ekonomi nasional, parsial dan tidak memihak nelayan tradisional, (2) sistem pemasaran hasil perikanan yang lebih menguntungkan pedagang perantara; (3) kerusakan ekosistem pesisir dan laut karena pencemaran dari wilayah darat; (4) praktek penangkapan ikan dengan bahan kimia, perusakkan terumbu karang dan konversi hutan bakau di kawasan pesisir, (5) penggunaan peralatan tangkap yang tidak ramah lingkungan, (6) terbatasnya pengolahan teknologi pengolahan hasil tangkap pasca penangkapan, (7) terbatasnya peluang-peluang kerja di sektor non perikanan yang tersedia di desadesa nelayan, (8) kondisi alam dan fluktuasi musim yang tidak memungkinkan nelayan melaut sepanjang ta-hun, dan (9) isolasi geografis desa nelayan yang mengganggu mobilitas barang, jasa, modal dan manusia.

\section{Kontribusi Theory Planned Behavior terhadap Persoalan Sifat Kepemilikan Ikan Laut sebagai Sumber Milik Bersama}

Salah satu persoalan ekonomis yang mendasar pada kerja penangkapan ikan laut adalah sifat kepemilikan ikan laut sebagai sumber milik bersama (Anderson, 1977), (Semedi, 2002). Keadaan ini mengakibatkan berkembangnya sifat individualistik yang tinggi di kalangan para nelayan bahwa semua nelayan berkeinginan untuk memetik manfaat sebesar-besarnya dari sumberdaya yang ada tanpa ada seorangpun di antara mereka yang mau melakukan sesuatu untuk menjaga agar sumberdaya tersebut tetap ada pada tingkat yang menguntungkan (Hardin, 1968). Salah satu alternatif untuk menjaga agar tragedi sumberdaya milik umum ini tidak terjadi, adalah diubahnya status dari milik umum (bukan milik siapapun) menjadi milik orang tertentu; agar stok ikan laut ini berada dibawah klaim kepemilikan tunggal (Scott, 1986). Dengan cara ini si pemilik dapat melakukan eksploitasi pada tingkat ekonomis yang optimal. Alternatif lain untuk mencegah tragedi sumberdaya milik bersama adalah dengan melakukan kontrol terhadap fishing effort, tingkat upaya penangkapan (Stokes, 1987), (Semedi, 2002). Di sini para nelayan diatur agar tidak melakukan penangkapan melewati daya dukung stok ikan yang ada.

Bagaimana upaya untuk melakukan kontrol terhadap fishing effort (tingkat upaya penangkapan) terhadap sumberdaya ikan di pantai Utara Provinsi Jawa Barat agar tragedi sumberdaya milik umum ini tidak terjadi? Jabaran hal tersebut pada Gambar 2. Pokok temuan dari hasil studi ini adalah bahwa keberadaan peubah niat untuk berperilaku yang berhubungan secara positif sebesar 0,68 terhadap peubah perilaku. Sementara itu perilaku yang diawali dengan niat untuk berperilaku merupakan perilaku yang didasari oleh adanya penggunaan informasi secara sistematik yang tersedia dari individu. Informasi sistematik yang mempengaruhi niat untuk berperilaku berasal dari pengaruh peubah sikap sebesar 0,26 ; peubah norma subjektif sebesar 0,46 dan peubah keyakinan kemampuan berperilaku sebesar 0,55. Dengan kata lain peningkatan satuan peubah sikap, norma subjektif dan peubah keyakinan kemampuan berperilaku selanjutnya akan meningkatkan satuan peubah niat untuk berperilaku dan satuan peubah perilaku. Oleh sebab itu untuk mendorong ke arah perilaku kontrol terhadap fishing effort tingkat upaya penangkapan ikan di pantai Utara Provinsi Jawa Barat dilakukan dengan meningkatkan satuan peubah sikap, norma subkektif, dan peubah keyakinan kemampuan berperilaku nelayan. Merujuk kepada temuan penelitian, maka peningkatan sikap positif nelayan dapat dilakukan dalam bentuk pemberian informasi melalui penyuluhan yang meningkatkan aspek kognitif (pengetahuan) nelayan khususnya dalam bidang (a) penggunaan alat tangkap, (b) pelaksanaan operasi penangkapan dan (c) menjaga mutu ikan hasil tangkapan.

Peningkatannorma subjektifuntukberperilaku positif nelayan dilakukan dalam bentuk pemberian informasi dan penyuluhan yang meningkatkan aspek kognitif punggawa khususnya dalam bidang (a) penggunaan alat bantu tangkap, khususnya dalam bidang, (b) operasi kegiatan penangkapan dan (c) menjaga mutu ikan hasil tangkapan. Peningkatan keyakinan kemampuan berperilaku nelayan ini dilakukan dalam bentuk pembuatan kebijakan yang 
mendorong nelayan dapat memiliki kemampuan berperilaku secara positif khususnya dalam bidang (a) penggunaan alat tangkap, (b) penggunaan alat bantu tangkap dan (c) persiapan operasi penangkapan.

\section{Kesimpulan}

Theory Planned Behavior dapat digunakan untuk melihat niat untuk ber-perilaku dan perilaku nelayan artisanal di pantai Utara Provinsi Jawa Barat, meskipun dimungkinkan adanya perilaku yang dilakukan tanpa melalui niat untuk berperilaku.

Faktor-faktor karakteristik demografi berpengaruh secara langsung pada sikap, norma subjektif dan keyakinan kemampuan berperilaku nelayan dalam kegiatan perikanan tangkap. Faktor sikap, norma subjektif dan keyakinan kemampuan berperilaku berpengaruh secara langsung pada niat untuk berperilaku nelayan dalam kegiatan perikanan tangkap. Faktor niat untuk berperilaku berpengaruh secara langsung pada perilaku nelayan dalam kegiatan perikanan tangkap.

Koefisien determinasi antara peubah sikap, norma subjektif, keyakinan kemampuan berperilaku peubah niat untuk berperilaku sebesar 0,64. Kondisi ini mengindikasikan adanya faktor peubah lain sebesar $36 \%$ di luar peubah penelitian ini yang mempengaruhi niat untuk berperilaku. Sementara itu koefisien determinasi peubah perilaku sebesar $0,47 \%$ yang mengindikasikan adanya pengaruh peubah lain sebesar $53 \%$ di luar peubah niat untuk berperilaku yang mempengaruhi perilaku nelayan. Dengan kata lain bahwa tidak sepenuhnya niat untuk berperilaku nelayan terwujud sesuai dengan perilaku mereka dalam kegiatan perikanan tangkap.

Temuan penelitian ini yang menjelaskan tentang faktor-faktor yang mempengaruhi perilaku nelayan artisanal dalam pemanfaatan sumberdaya perikanan, dapat memberikan kontribusi terhadap persoalan sifat kepemilikan ikan laut sebagai sumber milik bersama di wilayah studi dan komanajemen perikanan di Indonesia, khususnya pada komunitas di wilayah studi di pantai Utara Provinsi Jawa Barat.

\section{Daftar Pustaka}

Abrecombi N. (1984). Dictionary of Sociology. New York: Penguin Books.

Agnes M. (2000). Webster's New World College.
IDG India. Ajzen, Icek, 2005. Attitudes, Personality and Behaviour, New York: McGraw Hill Education.

Satria A. (2002). Pengantar Sosiologi Masyarakat Pesisir. Jakarta: Cidesindo.

Arifin, Suarif FX. (1995). Hubungan Sikap dan Norma Subjektif dengan Intensi Bersanggama pada Mahasiswa di Jakarta, Jakarta:. Program Pascasarjana Fakultas Psikologi, Universitas Indonesia. Photocopied.

Aldirch. (2009). The Development of Effective Message Content for Suicide Intervention Theory Planed Behavior dalam Journal of Crisis. 30(4): 174 - 179. [Internet]. [dapat diunduh dari: www.proquest.pqd/web]

Majali AL, Malek. (2010). Application of Decomposed Theory Planned behaviour on Internet Banking Adoption in Jordan, dalam Journal of Internet Banking and Commerce. 12(2). [Internet]. [dapat diunduh dari: www. proquest.pqd/web]

Beedell J, Rehman T. (2000). Using Social Psychology Models to Understand Farmers' Conservation Behaviour dalam Journal of Rural Studies. [internet]. [dapat diunduh dari: www. proquest.pqd/web].

Bright AD. (1993). Application of the theory of reasoned action to the national park service's controlled burn policy dalam Journal of Leisure Research. 25(3), $263-281$.

Burton RJF. (2004). Reconceptualizing the "behavior approach" in agricultural studies: a socio-psychological perspective, dalam Journal of Rural Studies, 20(2004). 359-371. [Internet]. [dapat diunduh dari: www.jstore.org]

Balai Pustaka. (2001). Kamus Besar Bahasa Indonesia. Jakarta (ID): Balai Pustaka.

Bandura A. (1977). Social Learning Theory. New Jersey: Prentice-Hall.

Berkes F, Mahon R, McConney P, Pollnac R, Pomeroy R. (2001). Managing Small-scale Fisheries: Alternative Directions and Methods. Otawa: International Development Research Center.

Bohannan P. Glazer M. (1988). High Point in Anthropology. New York. Alfred A. Knopf.

Badan Perencanaan Daerah Provinsi Jawa Barat. (2007). Rencana Arah Pengembangan Bisnis Kelautan Jawa Barat. Bandung (ID): Bappeda 
Provinsi Jawa Barat.

Budiono, Pitojo R. (2006). Karakteristik Petani Tepi

Hutan dan Keyakinan kemampuan berperilaku nya dalam Pelestarikan Hutan Lindung di 12 Desa di Provinsi Lampung. Bogor (ID): Sekolah Pascasarjana Institut Pertanian Bogor. Photocopied.

Brophy, Jere E, Good TL. (1990). Educational Psychology Realistic Approach. Londin: Longman,

Budi, Siswanto. (2008). Kemiskinan dan Perlawanan Kaum Nelayan. Malang: Laskbang Mediatama.

Charles TA. (2001). Sustainable Fishery System. London: Blackwell Science.

Carey KB. (2007). The Theory Planned Behavior as A Mode of Heavy Episodic Drinking Among College Student, dalam Journal Psychology of Addictive Behavior. 21(4): 498 - 507. www. proquest.pqd/web

Conner M. et al,. (2002). The Theory Planned behavior and Health Eating, dalam Journal Health Psychology. 21(2): 194 - 201. [Internet]. [dapat diunduh dari: www.proquest.pqd/web]

Eagly AH, Crowley M. (1986). The Psychology of Attitudes. New York: Brace Jovanovich College.

Eriyanto, (2007). Teknik Sampling: Analisis Opini Publik. Yogyakarta (ID): LKIS.

Elliot, Mark A, (2003). Driver,s Compliance with Speed Limit: An Application of The Theory Planned Behavior dalam Journal of Applied Psychology. 88(5): 964 - 972. [Internet]. [dapat diunduh dari: www.proquest.pqd/web]

Emmerson DK. (1982). Order of meaning: understanding political change in a fishing community in Indonesia, dalam Anderson, Benedictand Kahin, Audrey (editor). Interpreting Indonesia Politic: Thirteen Contribution to the Debate. Ithaca: Cornell Modern Indonesian Project.

Fauzi A. (1998). The Management of Competing Multi Species Fisheries: A Case Study of Small Pelagic Fisheries on North Coast of Central Java. Canada: Simon Fraser University. [Internet]. [dapat diunduh dari: www.proquest. $\mathrm{pqd} / \mathrm{web}]$

Firth R. (1971). Malay Fishermen: Their Peasant Economy. London: Routledge \& Keagan Paul Ltd.

Fishbein A. (1975). Belief, Attitude, Intention and Behavior: A Introduction to Theory and Research. Canada: Addison-Wesley.

Fishbein A. (2005). Attitudes, Personality and Behavior. New York: Open University Press.

Ginis M. (2007). Using Theory Planned behavior to Predict Leisure Time Physical Activity among People with Chronic Kidney Disease dalam Journal Rehabilitayion Psychology. 52(4): 435 - 442. [Internet]. [dapat diunduh dari: www. proquest.pqd/web]

Hadari, Nawawi, dan Martini, Hadari. (2006). Instrumen Penelitian Bidang Sosial. Yogyakarta (ID): Gadjah Mada University Press.

Hamzen WPS. (2007). Pengembangan Mutu Sumberdaya Manusia Nelayan: Kasus Nelayan Kecil di Pangkalan Pendaratan Ikan Muara Angke, Provinsi DKI Jakarta. Bogor (ID): Sekolah Pascasarjana Institut Pertanian Bogor. Photocopied.

Hersey P. (1996). Management of Organization Behavior. Utilizing Human Resources. New York: Prentice Hall.

Horne C. (2001). Sociological Perspective on the Emergence of Social Norm dalam Social Norms, eds. Michael Hechter dan Karl Dieter Opp. New York. Russel Sage Foundation.

Hardin G. (1968). Tragedy of the commons dalam Science (162): 1243 - 1248.

Istiqlaliyah M. (2010). Kondisi Sosial Ekonomi dan Tingkat Kesejahteraan Keluarga: Kasus di Wilayah Pasisir Jawa Barat, dalam Jurnal Ilmu Keluarga. IPB Bogor. Januari 2010. 1 - 10.

Kerlinger FN. (2004), Azas-azas Penelitian Behavioral. Yogjakarta (ID): Gadjahmada University Press.

Kusnadi. (2000). Nelayan: Strategi Adaptasi dan Jaringan Sosial. Bandung (ID): Humaniora Utama Press.

Kusnendi. (2008). Model-model Persamaan Struktural, Satu Multigoup Sampel dengan Lisrel. Bandung (ID): Penertbit Alfabeta.

Lionberger HF. (1980). Adoption of New Ideas and Practice. Missouri. The Iowa State Univrsity Press.

Luky A. (2007). A Snapshot on Small Scale Fisheries. Sebuah Pengangar Focus Group Discussion. PKSPL IPB.

Luky A, Kusumastanto T, Damar A. (2006). Pengelolaan Wilayah Pesisir dan Laut. Jakarta 
(ID): Universitas Terbuka Press.

Luky A, Hartato DI, Kalikoski D, Yunanda T. (2009).

Peningkatan Kapasitas untuk Pengarus-Utamaan

Ko-Manajemen Perikanan di Indonesia. Jakarta (ID): FOA dan DKP.

Margono S. (2003). Memantapkan Penyuluhan Pertanian di Indonesia, dalam Membentuk Pola Perilaku Manusia Pembangunan. Bogor (ID): IPB Press.

Mardin. (2009). Faktor-faktor yang Berpengaruh pada Kemandirian Nelayan Ikan Demersal di Kecamatan Wangi-wangi Selatan Kabupaten Wakatobi, Sulawesi Tenggara. Bogor (ID): Sekolah Pascasarjana Institut Pertanian Bogor. Photocopied.

Maslow A. (1954). A Motivation and Personality. New York; Harper \& Row.

Myer DG. (1996). Social Psychology. New York: McGraw Bile.

Morris CP. (1995). Recruiting the new conservationist: farmer's adoption of Agri environmental schemes in the UK, dalam Journal of Rural Studies 11. 51 - 63.

Pambudy R. (1999). Perilaku Komunikasi, Perilaku Wirausaha Peternak dan Penyuluhan dalam Sistem Agribisnis Peternak Ayam. Bogor (ID): Sekolah Pascasarjana Institut Pertanian Bogor. Photocopied.

Polnac RB. (1988). Karakteristik Sosial dan Budaya dalam Pembangunan Berskala Kecil dalam Mengutamakan Manusia dalam Pembangunan Pembangunan Pedesaan editor Cernea Michael Jakarta (ID): UI Press.

Semedi P. (2002). Close to the stone, far from the throne: The story of a Javanese community 1820s - 1990s. Yogyakarta (ID): Benang Merah.

Potter C. (1995). Recruiting the new conservationist: farmer's adoptions of agricultural. Environmental schemes in the UK.dalam Journal of Rural Studies. 11. 51 - 63. [Internet]. [dapat diunduh dari: www.proquest.pqd/web]

Semedi P. (2002). Otonomi Daerah di Sektor Penangkapan Ikan, dalam Jurnal Populasi, 13 (1).

Tahir R. (2000). Using social-psychology models to understand famer's conservation behavior, dalam Journal of Rural Studies. 16. 117 - 127. [Internet]. [dapat diunduh dari: www.proquest. $\mathrm{pqd} / \mathrm{web}]$
Ritzer G, Goodman DJ. (2004). Sociological Theory. New York: McGraw-Hill.

Dahuri R. (1996). Pengelolaan Sumberdaya Wilayah Pesisir dan Lautan Secara Terpadu. Jakarta (ID): PT. Pradnya Paramita.

Ruben BD. (1992). Communication and Human Behavior. New Jersey: Prentice Hall.

Ryan JM. (2010). Usiang the Theory Planned Behavior to Predict Gambling Behavior, dalam Journal Psychology of Addictive Behavior. 24. (1): 89 - 98. [Internet]. [dapat diunduh dari: www.proquest.pqd/web]

Amanah S. (2006). Pengembangan Masyarakat Pesisir berdasarkan Kearifan Lokal: Kasus Kebupaten Buleleng, Provinsi Bali. Bogor (ID): Sekolah Pascasarjana Institut Pertanian Bogor. Photocopied.

Suparta, N. (2005). Perilaku Agribisnis dan Kebutuhan Penyuluhan Peternak Ayam Ras Pedaging. Bogor (ID): Sekolah Pascasarjana Institute Pertanian Bogor,

Seen CY. (2001). Predictor of Intention to Use Condoms Among University Women: An Application and Extension of the Theory Planed Behavior, dalam Canadian Journal of Behavior Science. 33(2): 103 -117. [Internet]. [dapat diunduh dari: www.proquest.pqd/web]

Sarwono SW. (2002). Psikologi Sosial: Individu dan Teori-teori Psikologi Sosial. Jakarta (ID): Balai Pustaka.

Saifuddin A. (2003). Reliabilitas dan Validitas. Yogyakarta (ID): Pustaka Pelajar. Salkind, N.J. 1985. Theories of Human Development. New York. John Willey and Sons. Inc.

Seymour SC. (2000). Macmillan Dictionary of Anthropology. New York: Macmillan Reference Books.

Sutejo KW. (2007). Dinamika Kebijakan terhadap Nelayan: Tinjauan Historis pada Nelayan Pantura Jawa. Fakultas Sasta Universitas Diponegoro. Photocopied.

Taswa S. (1995). Kajian Kelembagaan Transaksi dalam Pemasaran Hasil Usaha Penangkapan Ikan di Jawa Timur Bogor: Sekolah Pascasarjana IPB. Photocopied .

Triandis HC. (1971). Attitude and Attitude Change. New York: John Willey \& Sons, Inc.

Wijanto SH. (2008). Structural Equation Modeling dengan Lisrel 8,8: Konsep dan Tutorial. 
Yogjakarta (ID): Grhaha Ilmu

Vander Z, James W. 1995. Human Development. New York: McGraw-Hill, Inc.

Zulfarima. (2003). Persepsi dan Partisipasi Petani terhadap Usaha Pertanian Konservasi:

Studi Kasus Kelompok Pengelola Hutan Kemasyarakatan di Kawasan Hutan Lindung Register 45 B. Kabupaten Lampung Barat. Provinsi Lampung. Bogor (ID): Sekolah Pascasarjana Institut Pertanian Bogor. Photocopied.
Undang-undang Nomor 27 Tahun 2007 tentang Pengelolaan Wilayah Pesisir dan Pulau-pulau Kecil.

Undang-undang Nomor 16 Tahun 2006 tentang Sistem Penyuluhan Pertanian, Perikanan dan Kehutanan

Tridoyo K. (2004), Menggugat Revolusi Biru dalam Sinar Harapan. Sinar Harapan. 